\title{
FAKTOR YANG MEMPENGARUHI KESEHATAN POPULASI Rhizophora apiculata BERDASARKAN KARAKTERISTIK LINGKUNGAN PADA KAWASAN INDUSTRI PERMINYAKAN DAN NON KAWASAN INDUSTRI DI PROVINSI RIAU MENGGUNAKAN ANALISIS KOMPONEN UTAMA (PCA)
}

\author{
Syahrial $^{1}$, Dietriech G Bengen ${ }^{2}$, Tri Prartono ${ }^{2}$, Bintal Amin ${ }^{3}$ \\ ${ }^{1}$ Sekolah Tinggi Perikanan dan Kelautan MATAULI \\ Kabupaten Tapanuli Tengah \\ ${ }^{2}$ Departemen IImu dan Teknologi Kelautan, Institut Pertanian Bogor \\ ${ }^{3}$ Jurusan IImu Kelautan, Universitas Riau \\ Email: syahrial.bmc@gmail.com
}

Received August 2018, Accepted September 2018

\begin{abstract}
ABSTRAK
Kajian faktor penentu kesehatan populasi Rhizophora apiculata telah dilakukan pada ekosistem mangrove sekitar kawasan industri perminyakan dan non kawasan industri di Provinsi Riau yang berdasarkan karakteristik lingkungannya dengan menggunakan Analisis PCA. Penelitian ini dilaksanakan pada bulan November hingga Desember 2014 di pesisir pantai Kota Dumai dan Kabupaten Bengkalis dengan tujuan sebagai dasar evaluasi terhadap pengelolaan mangrove di Provinsi Riau kedepannya. Pengukuran kualitas perairan dilakukan dengan cara insitu dan sampel sedimen diambil menggunakan eckman grab pada daerah intertidal dengan kedalaman air $5-10 \mathrm{~m}$. Hasil penelitian menunjukan bahwa kondisi kesehatan populasi $R$. apiculata dipengaruhi oleh tiga faktor. Faktor pertama adalah parameter logam berat $\mathrm{Pb}, \mathrm{pH}$, suhu dan DO. Faktor kedua adalah parameter TPH dan trigliserida. Sementara faktor ketiga adalah salinitas dan potensial redoks. Kemudian masingmasing faktor memiliki nilai varian yang berbeda-beda yakni 33.36\% (faktor pertama), 30.34\% (faktor kedua) dan 15.57\% (faktor ketiga). Dari ketiga faktor tersebut, yang paling mempengaruhi kondisi kesehatan populasi $R$. apiculata pada kawasan industri perminyakan dan non kawasan industri di Provinsi Riau adalah parameter logam berat $\mathrm{Pb}, \mathrm{pH}$, suhu dan DO.
\end{abstract}

Kata Kunci : Kesehatan, Rhizophora apiculata, Mangrove, PCA, kawasan Industri, Riau

\section{ABSTRACT}

Analysis of determinant factor Rhizopora apiculata population health had been done in petroleum industry area and non-industry area of Riau 
Province, it based on Principal Component Analysis (PCA). This research was conducted on November - Desember 2014 in coastal area of Dumay City and Bengkalis Regency by aims as evaluation basic to mangrove management of Riau Province for the future. Waters quality measurement was done by insitu method and sedimen sampling was taken by use eckman grab on intertidal area, where deeps at $5-10 \mathrm{~m}$. The result showed that condition of $R$. apiculata population health was influenced by 3 factors. First factors were heavy logam $\mathrm{Pb}, \mathrm{pH}$, temperature and $\mathrm{DO}$. Second factors were TPH and trigliserida. While, thirth factors were salinity and oxydation reaction potential. Each factor had different varian, those were 33.36\% (first factor), 30,34\% (second factor) and 15.57 (thirth factor). From 3 factors, the most influenced factor to condition of $R$. apiculata population health in petroleum industry area and non-industry area of Riau Province was heavy logam $\mathrm{Pb}, \mathrm{pH}$, temperature and $\mathrm{DO}$.

Keywords : Health, Rhizophora apiculata, Mangrove, PCA, Industry Area, Riau

\section{PENDAHULUAN}

Hutan mangrove memiliki banyak manfaat, misalnya sebagai zona perangkap yang baik terhadap puing-puing laut dan darat (Udechukwu et al. 2014), memainkan peran utama dalam siklus biogeokimia dan bertindak sebagai reservoir dalam asimilasi tersier limbah (Tripathi et al. 2016), mengurangi intrusi air laut ke daerah-daerah pesisir (Gillis et al. 2014), dapat menyerap karbon di atmosfer (Donato et al. 2011) hingga memiliki kapasitas untuk mengimbangi kenaikan permukaan laut (Kirwan dan Megonigal, 2013).

Di dunia, hutan mangrove tumbuh di zona intertidal pada daerah tropis dan subtropis (Brander et al. 2012; Wang et al. 2013; Du et al. 2013; Costanza et al. 2014; Giri et al. 2015) yang mencakup area sekitar 1.7 $\times 105 \mathrm{~km}^{2}$ di sepanjang garis pantai dunia (Sandilyan dan Kathiresan, 2014), terletak diantara $30^{\circ}$ Lintang Utara maupun Selatan dan tersebar di lebih 120 negara (Kuenzer et al. 2011) dengan luas mencapai 15 juta hektar (Lewis et al. 2011).

Menurut Wu et al. (2014) hutan mangrove saat ini sedang terpapar oleh pencemaran dari aktivitas manusia untuk pengembangan perkotaan dan industrialisasi di wilayah pesisir. Di China misalnya, diperkirakan jumlah pembuangan limbah industri ke Sungai Pearl River mencapai \pm 200 juta ton/tahun sehingga menyebabkan kesehatan dan integritas mangrovenya terganggu (Chen et al. 2006).

Di Provinsi Riau, terdapat dua (2) kawasan industri yang keberadaannya berada di pesisir pantai dan terdapat ekosistem mangrove disekitarnya. Dua kawasan industri tersebut adalah Kawasan Industri Dumai (KID) dan Kawasan Industri Bukit Batu (KIBB). KID merupakan kawasan industri yang memproduksi minyak maupun gas bumi, Crude Palm Oil (CPO) dan Virgin Coconut Oil (VCO), sedangkan KIBB 
merupakan kawasan industri yang mengolah minyak dan gas bumi dari Kota Dumai.

Terlepas dari banyaknya manfaat, distribusi maupun kondisi buruk ekosistem mangrove saat ini, PCA (Principal Component Analysis) merupakan suatu analisis yang menjelaskan struktur varian kovarian dari suatu himpunan variabel yang melalui beberapa kombinasi linear dari berbagai variabel (Johnson dan Wichern, 2007). Kemudian Ulqodry et al. (2010) juga menjelaskan bahwa PCA merupakan metoda statistik deskriptif yang dapat digunakan untuk menampilkan data dalam bentuk grafik dan informasi maksimum yang terdapat dalam suatu matriks data. Matriks data yang dimaksud terdiri dari stasiun penelitian (baris) dan variabel lingkungan (kolom). Selanjutnya Bengen (2000) dan Pradhan et al. (2009) menyatakan bahwa PCA bertujuan untuk mengekstraksi data kualitas lingkungan menjadi suatu informasi dalam bentuk matriks yang memiliki kemiripan atau hubungan antar atribut dan dalam bentuk grafik yang mudah diintepretasikan. Selain itu, PCA juga bertujuan untuk mendeterminasi sumbu-sumbu optimum tempat diproyeksikannya individu-individu dan/atau variabel-variabel (Ulqodry et al. 2010).

Pemahaman tentang struktur hutan mangrove secara ekologis sangat penting karena berguna bagi pengelolaan dan konservasi yang berkelanjutan (Analuddin et al. 2013). Mengingat minimnya kajian tentang kesehatan mangrove dan pentingnya ekosistem mangrove bagi kehidupan biota pesisir maupun laut serta padatnya aktivitas industri minyak di Provinsi Riau, maka kajian faktor penentu kesehatan populasi Rhizophora apiculata di kawasan industri perminyakan dan non kawasan industri berdasarkan karakteristik lingkungan sangat perlu dilakukan. Hal ini bertujuan sebagai dasar evaluasi terhadap pengelolaan mangrove di Provinsi Riau kedepannya.

\section{MATERI DAN METODE}

\section{Waktu dan Tempat Penelitian}

Penelitian dilaksanakan pada bulan November hingga Desember 2014 di pesisir pantai Kota Dumai dan Kabupaten Bengkalis (Gambar 1). Stasiun 1 adalah ekosistem mangrove di sekitar KID Lubuk Gaung yang merupakan kawasan industri CPO (Kota Dumai), Stasiun 2 di ekosistem mangrove sekitar KID Bukit Kapur Raksa yang merupakan gabungan kilang minyak Pertamina Refinery Unit II Dumai, Chevron dan industri CPO (Kota Dumai). Sementara Stasiun 3 adalah ekosistem mangrove di sekitar KIBB yang merupakan kilang minyak Pertamina UP II Pakning (Kabupaten Bengkalis) dan Stasiun 4 adalah ekosistem mangrove di Tanjung Medang Rupat Utara yang merupakan kawasan alami mangrove, dimana tidak ada aktivitas industri di sekitarnya (Kabupaten Bengkalis). 


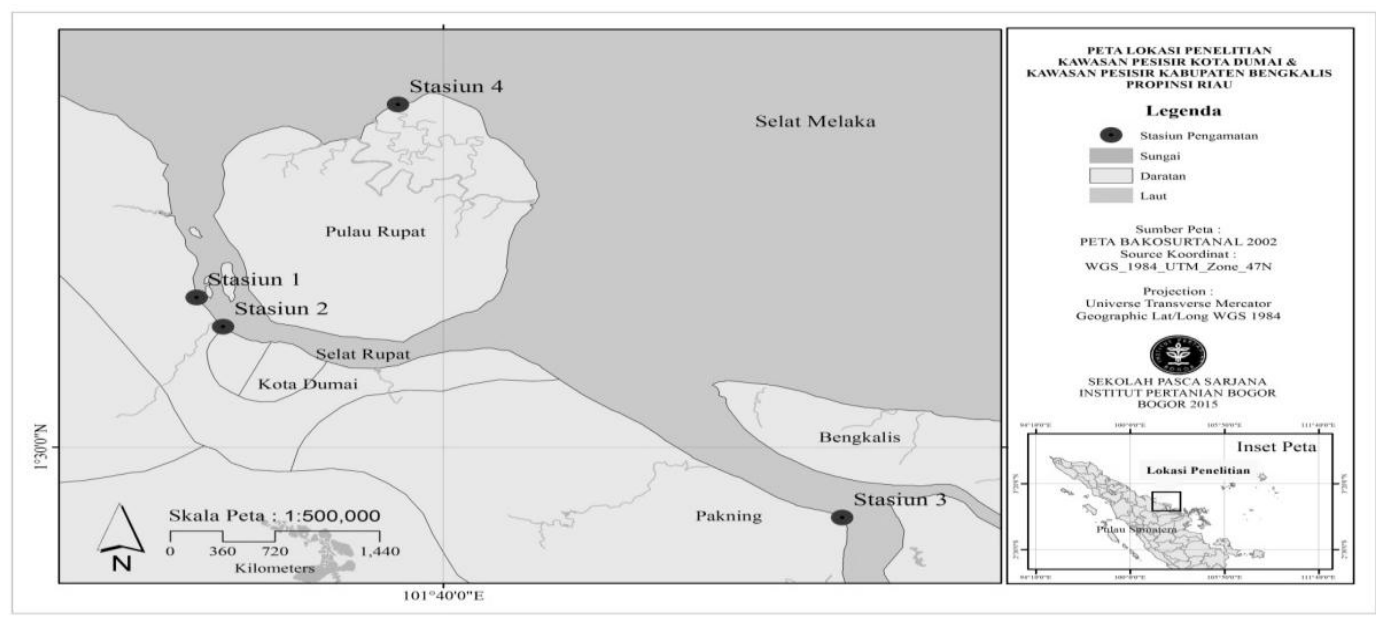

Gambar 1. Peta lokasi penelitian di kawasan industri perminyakan Kota Dumai dan Kabupaten Bengkalis

\section{Alat dan Bahan Penelitian}

Peralatan yang digunakan selama di lapangan adalah rol meter, buku identifikasi mangrove Noor et al. (2006), data sheet, kamera, GPS Garmin Montana 650, water quality meter (suhu, DO, salinitas, pH), ORP meter Lutron 203, eckman grab dan cool box. Sementara alat yang digunakan di laboratorium adalah oven, alat penumbuk (mortar), ayakan bertingkat, kertas saring whattman No. 1, Atomic Absorption Spectroscopy (AAS) Perkin Elmer 3110, timbangan analitik dan gelas ukur. Kemudian bahan yang digunakan selama penelitian adalah larutan $\mathrm{HNO}_{3}, \mathrm{HClO}_{4}$, aquades, Natrium Sulfat $\left(\mathrm{Na}_{2} \mathrm{SO}_{4}\right)$, pelarut petroleum ether $125 \mathrm{ml}$ dan sampel sedimen.

\section{Pengumpulan Data di Lapangan}

\section{Data Kualitas Perairan}

Pengukuran kualitas perairan dilakukan dengan cara insitu dengan mengambil contoh air pada masing-masing stasiun pengamatan. Parameter kualitas perairan yang diukur meliputi suhu perairan, $\mathrm{pH}$, salinitas dan oksigen terlarut (Dissolved Oxygen/DO) dengan menggunakan water quality meter, sementara Oksidasi Reduksi Potensial (ORP)/potensial redoks perairan diukur menggunakan ORP Meter Litron 203.

\section{Data Kualitas Sedimen (TPH, Trigliserida dan Logam Berat Pb)}

Sampel sedimen perairan diambil menggunakan eckman grab pada daerah intertidal dengan kedalaman air 5-10 m. Setiap stasiun dibagi atas tiga titik pengambilan sampel dengan jarak titik sampling $\pm 500 \mathrm{~m}$. 
Sampel sedimen yang didapat dimasukkan ke dalam kantong plastik, kemudian diikat dan dimasukkan ke dalam cool box. Selanjutnya dibawa ke laboratorium untuk dianalisis konsentrasi Total Petroleum Hydrocarbon (TPH), trigliserida dan logam berat $\mathrm{Pb}$.

\section{Pengumpulan Data di Laboratorium}

\section{Analisis Logam Berat $\mathrm{Pb}$}

Sampel diambil lebih kurang 150 gram pada masing-masing titik pengambilan sampel, kemudian dikeringkan dalam oven pada suhu $80^{\circ} \mathrm{C}$ sampai dicapai berat konstan. Sedimen yang telah kering, kemudian digerus dengan menggunakan alat penumbuk (mortar) dan selanjutnya diayak dengan menggunakan ayakan bertingkat untuk mendapatkan fraksi sedimen kecil dari 63 mikron, selanjutnya sampel didestruksi dalam kombinasi larutan $\mathrm{HNO}_{3}$ dan $\mathrm{HClO}_{4}$ dengan perbandingan 4:1 yang menggunakan block digester pada suhu rendah $\left(40^{\circ} \mathrm{C}\right)$ selama 1 jam dan kemudian suhu dinaikan menjadi $140^{\circ} \mathrm{C}$ selama 3 jam. Sampel sedimen yang terdestruksi secara sempurna, kemudian didinginkan dan diencerkan dengan aquades menjadi $40 \mathrm{ml}$ dan disaring dengan kertas whattman No. 1 (untuk menghindari penyumbatan pipa kapiler pada saat analisis sampel dengan AAS) dan disimpan dalam botol sampel (Mucha et al. 2003; Yap et al. 2002), kemudian sampel dianalisis kandungan logam beratnya satu per satu menggunakan AAS.

Perhitungan kandungan logam berat $\mathrm{Pb}$ sedimen berdasarkan Yap et al. (2002) dilakukan dengan rumus:

$$
C=\frac{A x V}{G}
$$

Dimana :

C : Konsentrasi yang sebenarnya dari sampel $(\mu \mathrm{g} / \mathrm{g})$

A : Nilai konsentrasi AAS $(\mu \mathrm{g} / \mathrm{ml})$

V : Volume sampel (ml)

G : Berat sampel (gr)

\section{Analisis Sampel Minyak}

Prosedur analisis kandungan minyak sedimen dilakukan dengan menggunakan metode soxhlet (Woodman dalam Sudarmadji et al.1997). Prinsip kerjanya adalah sampel sedimen yang telah diperoleh, ditimbang terlebih dahulu menggunakan timbangan analitik yang dialaskan dengan kertas saring dalam keadaan 0 (nol) gram, kemudian sebanyak $500 \mathrm{gr}$ sampel sedimen diletakkan di atas kertas saringan dan diberi larutan Natrium Sulfat $\left(\mathrm{Na}_{2} \mathrm{SO}_{4}\right) 1 \mathrm{gr}$, sehingga didapat berat sampel. Selanjutnya labu ditimbang untuk mendapatkan berat kosong dan soxhlet dipanaskan terlebih dahulu. Sampel yang telah ditimbang, kemudian dimasukkan ke 
dalam timbel ekstraksi soxhlet dan pendingin dialirkan melalui kondensor. Tabung ekstrasi dipasang pada alat distilasi soxhlet dengan pelarut petroleum ether $125 \mathrm{ml}$ per sampel selama 5 jam, kemudian dipindahkan ke dalam gelas ukur untuk dilihat sisa larutan yang terpakai. Hasil ekstraksi minyak dalam labu dimasukkan ke oven untuk pengeringan selama 2 jam dengan suhu $70^{\circ} \mathrm{C}$ sampai berat konstan. Berat residu dalam labu kemudian ditimbang untuk dinyatakan sebagai berat minyak.

\section{Analisis TPH dan Trigliserida dengan GC-MS}

Minyak yang diperoleh dari hasil analisis metode soxhlet, selanjutnya dianalisis untuk mengetahui konsentrasi TPH dan trigliseridanya menggunakan kromatografi gas-spektrometer massa (GCMS). Analisis TPH dengan GC-MS menggunakan kolom BD5 dilakukan dengan kondisi suhu kolom $60^{\circ} \mathrm{C}$, suhu detektor $300^{\circ} \mathrm{C}$, suhu injektor $270^{\circ} \mathrm{C}$, suhu deprogram awal $60^{\circ} \mathrm{C}$, selanjutnya dinaikkan $15 \mathrm{C} /$ menit$510^{\circ} \mathrm{C}$, waktu analisis dibutuhkan selama 30 menit, tekanan $80.2 \mathrm{kpa}$, laju alir $1.32 \mathrm{ml} / \mathrm{menit}$, split ratio 200 dan linear velocity $41.7 \mathrm{ml} / \mathrm{menit}$. (Munawar dan Zaidan, 2013).

Analisis trigliserida dilakukan menggunakan kolom Rtx-5MS dengan panjang $30 \mathrm{~m}$ dan diameter dalam kolom $0.25 \mathrm{~mm}$, dimana kondisi temperatur oven kolom $100^{\circ} \mathrm{C}$; temperatur injektor $300^{\circ} \mathrm{C}$; tekanan gas pembawa $22 \mathrm{kPa}$, laju alir total $80 \mathrm{ml} /$ menit, laju alir kolom 0.50 $\mathrm{ml} /$ menit, rasio split 153 , program temperatur $100^{\circ} \mathrm{C}$ (ditahan selama 5 menit), dinaikkan dengan laju $10^{\circ} \mathrm{C} /$ menit sampai dengan $270^{\circ} \mathrm{C}$ (ditahan selama 8 menit), temperatur sumber ion $250^{\circ} \mathrm{C}$, temperatur interface $300^{\circ} \mathrm{C}$ dan rentang deteksi $\mathrm{m} / \mathrm{z} 30-600$ (Tahir dan Yoeswono, 2009).

\section{Pengolahan Data Faktor Penentu Kesehatan Populasi $\boldsymbol{R}$. apiculata}

Untuk menentukan faktor-faktor yang menentukan kesehatan populasi $R$. apiculata antara kawasan industri perminyakan dan non kawasan industri digunakan analisis statistik multivariabel yang didasarkan pada Analisis Komponen Utama (AKU/PCA) menggunakan Statistical Package for Social Science (SPSS) versi 19.

\section{HASIL DAN PEMBAHASAN}

\section{Evaluasi Barlett Test of Sphericity dan KMO}

Menurut Riyani (2012) bahwa Barlett's test of sphericity merupakan suatu uji statistik yang dipergunakan untuk menguji hipotesis bahwa variabel tidak saling berkorelasi dalam populasi, sedangkan Kaisar-MeyerOlkin (KMO) Measure of Sampling Adequacy merupakan suatu indeks yang dipergunakan untuk meneliti ketepatan analisis faktor. Kemudian Umar (2009) menambahkan bahwa Bartlett's test of Sphericity adalah tes statistik untuk keseluruhan signifikansi dari semua korelasi di dalam suatu 
matriks korelasi yang ditandai dengan signifikansi ( $p$ value $<0.05$ ). Selanjutnya Martono et al. (2012) menyatakan bahwa data Barlett test of Sphericity dan KMO merupakan data yang digunakan untuk mengukur kecukupan sampel. Hal ini dilakukan dengan cara membandingkan besarnya korelasi yang diamati terhadap korelasi parsialnya, sehingga merupakan suatu syarat yang harus dilakukan sebelum menganalisis PCA. Berdasarkan Tabel 1 terlihat bahwa nilai Barlett test of Sphericity sebesar 61.353 lebih besar dari 0.5 dan memiliki nilai signifikansi sebesar 0.000 ( $p<0.05)$. Hal ini mengambarkan bahwa baik buruknya kondisi kesehatan populasi $R$. apiculata mempunyai korelasi yang sangat kuat terhadap faktor kualitas lingkungan, baik itu kualitas air maupun kualitas sedimennya. Nobi et al. (2010) menyatakan bahwa kualitas air dan sedimen sangat penting untuk kelangsungan hidup dan kesejahteraan sumber hayati, terutama di daerah pesisir dan muara. Kemudian Hamzah dan Pancawati (2013) menambahkan bahwa kondisi fisikokimia perairan akan berpengaruh terhadap kondisi sedimen, fisiologi maupun pertumbuhan mangrove.

Tabel 1. Hasil evaluasi Barlett Test of Sphericity dan KMO

\begin{tabular}{lrr}
\hline \multicolumn{2}{l}{ Kaiser-Meyer-Olkin Measure of Sampling } & 0.367 \\
Adequacy & & 61.353 \\
\hline Bartlett's test of & Approx. Chi-Square & 28 \\
Sphericity & Df & 0.000 \\
\hline
\end{tabular}

\section{Eigenvalue Hasil Analisis Komponen Utama}

Menurut Riyani (2012) eigenvalue merupakan jumlah varian yang dijelaskan oleh setiap faktor, dimana eigenvalue pertama kali muncul dalam menyelesaikan persamaan differensial (Fraleigh dan Beauregard, 1987). Tabel 2 merupakan nilai eigenvalue dari masing-masing variabel, dimana terlihat bahwa terdapat tiga (3) variabel baru yaitu Component 1 (2.67), 2 (2.43) dan 3 (1.25). Hal ini menjelaskan bahwa ada tiga faktor yang dapat mempengaruhi kondisi kesehatan populasi $R$. apiculata pada kawasan industri perminyakan dan non kawasan industri di Provinsi Riau. Selanjutnya, berdasarkan Tabel 2 dan Gambar 2 terlihat bahwa ketiga variabel baru yang terbentuk tersebut, masing-masing memiliki nilai varian sebesar 33.36\% (Component 1), 30.34\% (Component 2) dan 15.57\% (Component 3). Kemudian ketiga variabel baru tersebut juga mampu menjelaskan keragaman datanya sebesar 79.27\%. Martonoet al. (2012) dan Umar (2009) menyatakan bahwa variabel baru (component) yang terbentuk pada analisis PCA didasari oleh nilai eigenvaluenya yang lebih dari satu. 
Tabel 2. Nilai eigen hasil Analisis Komponen Utama (PCA)

\begin{tabular}{cccc}
\hline \multirow{2}{*}{ Component } & \multicolumn{3}{c}{ Initial Eigenvalues } \\
\cline { 2 - 4 } & Total & \% of Variance & Cumulative \% \\
\hline 1 & 2.67 & 33.36 & 33.36 \\
2 & 2.43 & 30.34 & 63.70 \\
3 & 1.25 & 15.57 & 79.27 \\
4 & 0.85 & 10.67 & 89.94 \\
5 & 0.57 & 7.14 & 97.08 \\
6 & 0.15 & 1.89 & 98.97 \\
7 & 0.08 & 0.95 & 99.92 \\
8 & 0.006 & 0.08 & 100.00 \\
\hline
\end{tabular}
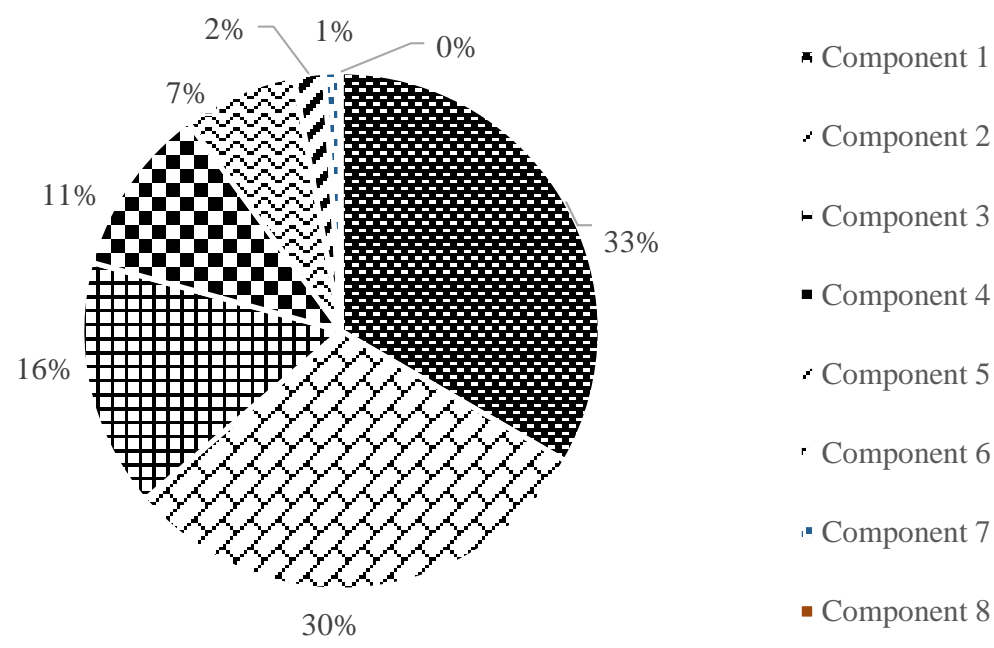

Gambar 2. Kontribusi masing-masing variabel (\% of variance)

\section{Rotasi Faktor Menggunakan Metodologi Varimax}

Martono et al. (2012) menyatakan bahwa untuk menentukan faktor apa saja yang termasuk dalam variabel baru hasil dari nilai eigenvalue, maka dilakukan rotasi faktor (transformasi) dengan menggunakan metodologi rotasi faktor varimax. Kemudian Martono et al. (2012) juga menyatakan bahwa rotasi faktor dengan menggunakan metodologi varimax merupakan hubungan (korelasi) antara variabel asli dengan variabel baru (principal component) yang dianalisis dengan PCA dan disebut dengan nilai loading.

Nilai loading yang dipilih adalah nilai loading di atas 0.5 (Martono et al. 2012). Hal ini dianggap mampu menjelaskan variabel dalam mempengaruhi kondisi kesehatan populasi $R$. apiculata pada kawasan industri perminyakan dan non kawasan industri di Provinsi Riau. Variabel lain yang memiliki nilai loading dibawah 0.5 dianggap tidak atau kurang berpengaruh terhadap kondisi kesehatan populasi $R$. apiculata pada 
kawasan industri perminyakan dan non kawasan industri di Provinsi Riau dan dengan menggunakan tiga variabel baru yang terbentuk tersebut telah dianggap mewakili 8 variabel yang aslinya.

Tabel 3 memperlihatkan bahwa faktor yang mempengaruhi kondisi kesehatan populasi $R$. apiculata pada kawasan industri perminyakan dan non kawasan industri di Provinsi Riau terbagi atas tiga (3) yakni parameter logam berat $\mathrm{Pb}, \mathrm{pH}$, suhu dan $\mathrm{DO}$ merupakan faktor pertama. Kemudian parameter TPH dan trigliserida adalah faktor kedua, sedangkan salinitas dan potensial redoks adalah faktor ketiga. Berdasarkan nilai varian yang dimiliki oleh tiap faktor, maka faktor pertama (logam berat $\mathrm{Pb}, \mathrm{pH}$, suhu dan DO) merupakan faktor yang paling mempengaruhi kondisi kesehatan populasi $R$. apiculata pada kawasan industri perminyakan dan non kawasan industri di Provinsi Riau. Hal ini disebabkan karena faktor pertama memiliki nilai varian yang lebih besar (33.36\%) bila dibandingkan dengan faktor yang lain. Menurut Ramanathan et al. (1999) lingkungan mangrove dengan kondisi air yang tertampung, memungkinkan pengendapan partikel halus dan biasanya diperkaya dengan logam berat. Kemudian rendahnya konsentrasi $\mathrm{pH}$ di sedimen mangrove, juga dapat meningkatkan mobilitas logam berat (Ho et al. 2012).

Tabel 3. Ringkasan Analisis Komponen Utama (PCA) populasi $R$. apiculata pada kawasan industri perminyakan dan non kawasan industri di Provinsi Riau

\begin{tabular}{clcc}
\hline $\begin{array}{c}\text { Principal } \\
\begin{array}{c}\text { Component } \\
(\mathrm{PC})\end{array}\end{array}$ & \multicolumn{1}{c}{$\begin{array}{c}\text { Nama } \\
\text { Variabel }\end{array}$} & $\begin{array}{c}\text { Faktor } \\
\text { Loading }\end{array}$ & $\begin{array}{c}\text { Varian } \\
\text { yang } \\
\text { dijelaskan } \\
(\%)\end{array}$ \\
\hline 1 & Logam berat Pb & 0.905 & 33.36 \\
& pH & 0.871 & \\
& Suhu & -0.685 & \\
& DO & -0.599 & 30.34 \\
& TPH & 0.983 & \\
& Trigliserida & 0.982 & 15.57 \\
& Salinitas & 0.916 & \\
\hline
\end{tabular}

\section{KESIMPULAN}

Faktor penentu kondisi kesehatan populasi $R$. apiculata pada kawasan industri perminyakan dan non kawasan industri di Provinsi Riau terbagi atas tiga (3) yakni pertama dipengaruhi oleh parameter logam berat $\mathrm{Pb}, \mathrm{pH}$, suhu dan $\mathrm{DO}$. Kedua dipengaruhi oleh parameter TPH dan trigliserida, sedangkan ketiga dipengaruhi oleh salinitas dan potensial redoks, dimana masing-masing faktor memiliki nilai varian secara berurutan sebesar 33.36\%, 30.34\% dan 15.57\%. Dari ketiga faktor penentu kondisi kesehatan populasi $R$. apiculata tersebut, parameter yang 
paling mempengaruhi kondisi kesehatan populasi $R$. apiculata adalah logam berat $\mathrm{Pb}, \mathrm{pH}$, suhu dan $\mathrm{DO}$.

\section{DAFTAR PUSTAKA}

Analuddin K, Jamili, Raya R, Septiana A, Rahim S. The spatial trends in the structural characteristics of mangrove forest at the Rawa Aopa Watumohai National Park, Southeast Sulawesi, Indonesia. IRJPS. 4(8): 214 - 221. Doi:10.14303/irjps.2013.047.

Bengen DG. 2000. Teknik Pengambilan Contoh dan Analisis Data Biofisik Sumberdaya Pesisir. PKSPL-IPB. Bogor (ID): IPB Pr.

Brander LM, Wagtendonk AJ, Hussain SS, McVittie A, Verburg PH, de Groot RS, van der Ploeg S. 2012. Ecosystem service values for mangroves in Southeast Asia: A meta-analysis and value transfer application. Ecos Serv. 1: $62 \quad$ - 69. Doi:10.1016/j.ecoser.2012.06.003.

Chen F, Yang Y, Zhang D, Zhang L. 2006. Heavy metals associated with reduced sulfur in sediments from different deposition environments in the Pearl River estuary, China. Environ Geochem Heal. 28: 265 272. Doi:10.1007/s10653-006-9042-4.

Costanza R, de Groot R, Sutton P, van der Ploeg S, Anderson SJ, Kubiszewski I, Farber S, Turner RK. 2014. Changes in the global value of ecosystem services. Glob Environ Chan. 26:152 - 158. Doi:10.1016/j.gloenvcha.2014.04.002.

Donato DC, Kauffman JB, Murdiyarso D, Kurnianto S, Stidham M, Kanninen M. 2011. Mangroves among the most carbon-rich forests in the tropics. Nat Geosc. 4: 293 - 297. Doi:10.1038/NGEO1123.

Fraleigh JB, Beauregard RA. 1987. Linear Algebra. Addison-Wesley Publishing Company. Inc, Rhode Island. 477 p.

Gillis LG, Bouma TJ, Jones CG, van Katwijk MM, Nagelkerken I, Jeuken CJL, Herman PMJ, Ziegler AD. 2014. Potential for landscape-scale positive interactions among tropical marine ecosystems. Mar Ecol Prog Ser. 503: 289 - 303. Doi:10.3354/meps10716.

Giri C, Long J, Abbas S, Murali RM, Qamer FM, Pengra B, Thau D. 2015. Distribution and dynamics of mangrove forests of South Asia. Environ Manag. 148: 101 - 111. Doi:10.1016/j.jenvman.2014.01.020.

Hamzah F, Pancawati Y. 2013. Fitoremidiasi logam berat dengan menggunakan mangrove. IIm Kel. 18(4): $203-212$. 
Martono GH, Adji TB, Setiawan NA. 2012. Penggunaan metodologi analisa komponen utama (PCA) untuk mereduksi faktor-faktor yang mempengaruhi penyakit jantung koroner. Dalam: Seminar Nasional Science, Engineering and Technology. 23 - 24 Februari 2012. Malang, Indonesia.

Ho HH, Swennen R, Cappuyns V, Vassilieva E, Gerven TV, Tran TV. 2012. Potential release of selected trace elements (As, Cd, Cu, Mn, $\mathrm{Pb}$ and $\mathrm{Zn}$ ) from sediments in Cam River-mouth (Vietnam) under influence of $\mathrm{pH}$ and oxidation. Scien Tot Environ. 435(436): 487 498. Doi:10.1016/j.scitotenv.2012.07.048.

Johnson R, Wichern D. 2007. Applied Multivariate Statistical Analysis. 6th ed. New Jersey (NJ): Pearson Prentice Hall.

Kirwan ML, Megonigal JP. 2013. Tidal wetland stability in the face of human impacts and sea-level rise. Nature. 504:53 - 60 . Doi:10.1038/nature12856.

Kuenzer C, Bluemel A, Gebhardt S, Quoc TV, Dech S. 2011. Remote sensing of mangrove ecosystems: A review. Rem Sens. 3:878 - 928. Doi:10.3390/rs3050878.

Lewis M, Pryor R, Wilking L. 2011. Fate and effects of anthropogenic chemicals in mangrove ecosystems: A review. Environ Poll. 159: 2328 - 2346. Doi:10.1016/j.envpol.2011.04.027.

Mucha AP, Vasconcelos MTSD, Bordalo AA. 2003. Macro benthic community in the Douro Estuary: relations with trace metals and natural sediment characteristics. Environ Poll. 121: 169 - 180. Doi:10.1016/S0269-7491(02)00229-4.

Munawar, Zaidan. 2013. Bioremediasi limbah minyak bumi dengan teknik biopile di lapangan Klamono Papua. Sains dan Mat. 1(2): 41 - 46.

Nobi EP, Dilipan E, Thangaradjou T, Silvakumar K, Kannan L. 2010. Geochemical and geo-statistical assessment of heavy metal concentration in the sediments of different coastal ecosystems of Andaman Islands, India. Est Coast Shelf Sci. 87: 253 - 264. Doi: 10.1016/j.ecss.2009.12.019.

Noor YR, Khazali M, Suryadiputra INN. 2006. Panduan Pengenalan Mangrove di Indonesia. Bogor (ID):PHKA/WI-IP.

Pradhan UK, Shirodkar PV, Sahu BK. 2009. Physico-chemical characteristics of the coastal water off Devi estuary, Orissa and 
evaluation of its seasonal changes using chemometric techniques. Cur Sci. 96(9): 1203 - 1209.

Ramanathan AL, Subramanian V, Ramesh R, Chidambaram S, James A. 1999. Environmental geochemistry of the Pichavaram mangrove ecosystem (tropical), southeast coast of India. Environ Geol. 37(3): 223 - 233. Doi:10.1007/s002540050380.

Riyani Y. 2012. Faktor-faktor yang mempengaruhi prestasi belajar mahasiswa (studi pada mahasiswa Jurusan Akuntansi Politeknik Negeri Pontianak). Eksos. 8(1): $19-25$.

Sandilyan S, Kathiresan K. 2014. Decline of mangroves e A threat of heavy metal poisoning in Asia. Ocean Coast Manag. 102: 161 - 168. Doi:10.1016/j.ocecoaman.2014.09.025.

Sudarmadji, Hargono S, Suhardi B. 1997. Prosedur Analisa untuk Bahan Makanan dan Pertanian. Yogyakarta (ID): Liberty.

Tahir I, Yoeswono. 2009. Optimasi proses transesterifikasi minyak sawit dengan methanol dan katalis $\mathrm{KOH}$ untuk pembuatan biodiesel. Dalam: Seminar Nasional Kimia Jurusan Pendidikan FMIPA Universitas Negeri Yogyakarta. 17 Oktober 2009. Yogyakarta, Indonesia.

Tripathi R, Shukla AK, Shahid M, Nayak D, Puree C, Mohanty S, Raja R, Lal B, Gautam P, Bhattacharyya P, Panda BB, Kumar A, Jambhulkar NN, Nayak AK. 2016. Soil quality in mangrove ecosystem deteriorates due to rice cultivation. Ecol Engin. 90: 163 - 169. Doi:10.1016/j.ecoleng.2016.01.062.

Udechukwu BE, Ismail A, Zulkifli SZ, Omar H. 2014. Distribution, mobility, and pollution assessment of $\mathrm{Cd}, \mathrm{Cu}, \mathrm{Ni}, \mathrm{Pb}, \mathrm{Zn}$, and $\mathrm{Fe}$ in intertidal surface sediments of $\mathrm{Sg}$. Puloh mangrove estuary, Malaysia. Environ Sci Pollut Res. 22(6): 4242 - 4255. Doi: 10.1007/s11356-014-36634.

Ulqodry TZ, Bengen DG, Kaswadji RF. 2010. Karakteristik perairan mangrove Tanjung Api-api Sumatera Selatan berdasarkan sebaran parameter lingkungan perairan dengan menggunakan analisis komponen utama (PCA). Maspari. 1: 16-21.

Umar HB. 2009. Principal Component Analysis (PCA) dan aplikasinya dengan SPSS. Kes Mas. 3(2): 97 - 101.

Wang Y, Qiu Q, Xin G, Yang Z, Zheng J, Ye Z, Li S. 2013. Heavy metal contamination in a vulnerable mangrove swamp in South China. 
Environ Monit Assess. 185: 5775 - 5787. Doi:10.1007/s10661-0122983-4.

Wu Q, Tame NFY, Leung JYS, Zhou X, Fu J, Yaoa B, Huang X, Xia L. 2014. Ecological risk and pollution history of heavy metals in Nansha mangrove, South China. Ecotox Environ Saf. 104: 43 - 51. Doi: 10.1016/j.ecoenv.2014.02.017.

Yap CK, Ismail A, Tan SG, Omar H. 2002. Concentrations of $\mathrm{Cu}$ and $\mathrm{Pb}$ in the offshore and intertidal sediments of the west coast of Peninsular Malaysia. Env Int. 28: 467 - 479. Doi:10.1016/S01604120(02)00073-9. 